DOI: 10.17234/SRAZ.65.2

\title{
Despre elementul romanic în limbile slave meridionale
}

\author{
Nicolae Saramandu \\ Institutul de Lingvistică "Iorgu Iordan - Alexandru Rosetti" \\ / Universitatea din Bucureşti \\ nicolaesaramandu@yahoo.com
}

Contribuțiile privind raporturile lingvistice româno-slave au o tradiție îndelungată atât în România cât şi în Croaţia. Este suficient să amintesc câteva nume, de la Petar Skok la August Kovačec în Croaţia sau de la Al. Rosetti la Emil Petrovici în România. Studiul elementului romanic în limbile slave meridionale se încadrează în cercetarea mai amplă privind elementul latin / romanic în limbile balcanice. Lucrările recente de geografie lingvistică reprezintă un progres în studiul limbii la nivel lexical, inclusiv în studiul împrumuturilor. Întemeindu-ne pe datele cuprinse în atlasele lingvistice, vom readuce în discuție câteva aspecte privind vechimea elementului romanic în limbile sud-slave şi răspândirea lui teritorială. Ne propunem să oferim totodată o imagine de ansamblu asupra romanității orientale pe baza contribuțiilor recente.

Cuvinte cheie: raporturile lingvistice româno-slave, elementul romanic, limbi balcanice, romanitate orientală, atlase lingvistice

Studiul raporturilor dintre limba română şi limbile slave meridionale au o lungă tradiţie atât în România cât şi în Croaţia, de la Sextil Puşcariu şi Theodor Capidan la Haralambie Mihăescu în România, de la Petar Skok la August Kovačec şi Goran Filippi în Croația. Au fost consacrate cercetări ample influenței slave asupra limbii române, la care s-au adăugat cele referitoare la prezența elementelor româneşti şi romanice în limbile slave meridionale.

În ceea ce priveşte acest al doilea aspect sunt de menționat câteva studii fundamentale, datorate lui Theodor Capidan, Raporturile lingvistice slavo-române. Influența română asupra limbii bulgare (Cluj, 1923), Petar Skok, Zum Balkanlatein, o serie de studii publicate în perioada 1926-1934 în „Zeitschrift für romanische Philologie" şi lucrarea de sinteză La romanité dans le sud-est de l'Europe (Bucureşti, 1993), datorată lui Haralambie Mihăescu.

Aş adăuga la aceste lucrări studiul de mai mică întindere al lui Giorge Pascu, Rumänische Elemente in der Balkansprachen (Gèneve, 1924), elaborat în paralel cu cel datorat lui Th. Capidan, în care lingvistul ieşean se ocupă şi de elementele româneşti din limbile bulgară, sârbă şi croată. 
Menţionăm, de asemenea, contribuțiile, mai recente, ale lingvistului bulgar Maxim Mladenov: Bălgarsko-rumănski ezikovi areali, în „Die slawischen Sprachen”, V, 1983, p. 49-70 (cu 30 de hărți); Arealna harakteristika na romanski elementi v bălgarskite dialekti, în „Die slawischen Sprachen”, XII, 1987, p. 75-122 (cu 41 de hărți), în care problematica în discuţie e tratată din perspectiva geografiei lingvistice. Hărţile din acest articol sunt Mladenov, Maxim (1987). Arealna harakteristika na romanski elementi v bălgarskite dialekti, în Die slawischen Sprachen, XII, p. 75-122.

Vom urmări în articolulde față influența exercitată de limba română asupra limbii bulgare - la nivel lexical - din perspectiva geografiei lingvistice. Această nouă perspectivă în studiul raporturilor lingvistice dintre cele două limbi ne-a fost înlesnită de publicarea, în perioada recentă, a Atlasului dialectal bulgar. Studierea elementului slav din limba română din perspectiva geografiei lingvistice s-a făcut în România după publicarea, în anii '40 ai secolului trecut, a Atlasului lingvistic român. Asimilarea, în ținuturile din nordul Dunării, a slavilor pune în evidență existența unei populații romanizate numeroase, statornice, care a locuit aceste ținuturi în continuitate teritorială şi temporală. Fenomenul invers s-a produs în sudul Dunării, unde populația romanizată a fost asimilată de slavi, lăsând urme în limba acestora.

Influența latino-romanică s-a exercitat asupra limbii bulgare în diferite perioade istorice, începând cu secolul al VII-lea, când slavii pătrund în sudul Dunării, până în zilele noastre. Hărțile lexicale ale Atlasului dialectal bulgar permit o asemenea delimitare în timp, dar şi o delimitare în spațiu, prin raportare la elementul latino-romanic prezent în limbile sârbă şi croată. În legătură cu acest aspect, menţionăm delimitarea pe care o făcea Sextil Puşcariu între românii răsăriteni, de pe teritoriul actualei Bulgarii şi românii apuseni, de pe teritoriul Serbiei: „În nordul Peninsulei Balcanice, pe teritoriul odinioară romanic [...], slavii se diferenţiau din ce în ce mai mult în sârbi şi bulgari. Se pare că şi românii supuşi acestor două popoare începură să se despartă în două grupuri, pe care le putem numi românii apuseni şi românii răsăriteni" (Sextil Puşcariu, Studii istroromâne, II, 1926, p. 362). Din românii răsăriteni ar proveni aromânii şi meglenoromânii; din românii apuseni ar proveni istroromânii (op. cit., p. 363-365). Chiar dacă această delimitare nu a fost, în general, acceptată în lingvistica românească în ceea ce priveşte originea dialectelor româneşti - singurul care a acceptat-o a fost Th. Capidan (discipol al lui Sextil Puşcariu), care plasa teritoriul unde s-a format dialectul aromân în partea răsăriteană a Bulgariei, la est de jatova granica - ea are o anumită semnificație dacă luăm în considerare caracterul influenței romanice şi româneşti în limbile sârbă, respectiv bulgară. Este vorba de o serie de particularităţi lingvistice prin care limbile română şi bulgară - nu şi limba sârbă - participă la aşa-numitele „,concordanțe lingvistice balcanice”, ; în fonetică: prezența vocalei de timbru $\breve{a}$ în seria centrală; neutralizarea opoziției privind gradul de deschidere între vocalele $e-i, o-u$ în poziție neaccentuată; în structura gramaticală: articolul postpus, dispariţia infinitivului (parţială în limba română; apare în dialectele aromân şi meglenoromân), flexiunea analitică etc. Unele dintre aceste particularităti apar şi în alte limbi balcanice (albaneză, neogreacă), semnificativ este însă faptul că ele sunt caracteristice domeniului dialectal bulgar, nu şi celui sârb. 
БУЗА cu sensul 'parte a feței, obraz' se întâlneşte într-o arie întinsă pe teritoriul bulgar, care se prelungeşte în nordul Greciei (Macedonia, Tracia) şi în Turcia europeană. Termenul se regăseşte în zona Vidin şi într-o arie restrânsă din vestul Republicii Macedonia de Nord, la graniţa cu Albania, ca şi într-o mică enclavă de limbă slavă în estul Albaniei (la graniţa cu Grecia). Buză provine în română din substratul autohton şi face parte din fondul lexical comun românei şi albanezei. În bulgară БУЗА provine din română. Sensul 'parte a feței, obraz' cu care БУЗА apare în limba bulgară, dar şi în albaneză (ca şi dialectul aromân: búḑa de्र-amáre 'malul mării') e mai apropiat de înţelesul originar, de 'margine, parte laterală' al cuvântului (cf. top. Byzantin 'oraşul de la marginea mării'; ILR II: 329, Brâncuş 53).

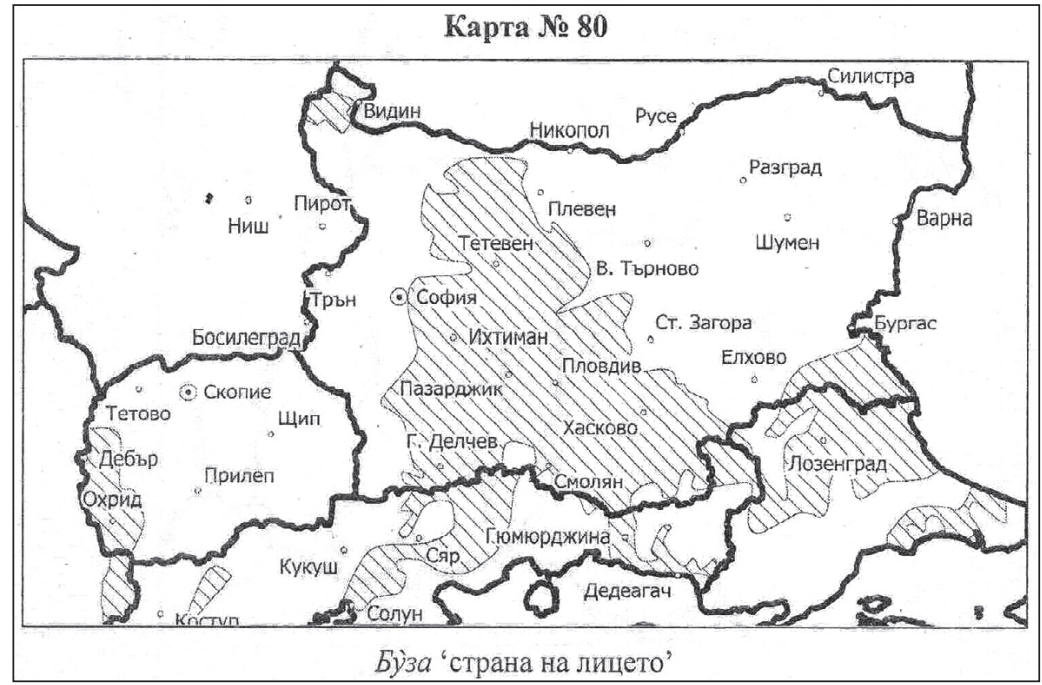

Este interesant să remarcăm faptul că într-o arie relativ extinsă, aflată în continuitate, la est, care se întinde de la Dunăre la Marea Neagră (cuprinzând oraşele Veliko Tărnovo, Şumen, Sliven, Burgas), termenul folosit este CTPAHA '(lit.) parte, latură, parte laterală', un calc după БУЗА, ceea ce confirmă vechimea acestui cuvânt în bulgară.

CKÓMEH cu sensul 'scaun' este astăzi un termen dialectal în limba bulgară, nefiind înregistrat în dicționarele curente. Dintre limbile sud-slave, apare numai în limba bulgară, într-o arie destul de largă, compactă, în nord-estul Bulgariei şi în câteva puncte izolate din extremitatea sud-vestică. Intrat în bulgară prin

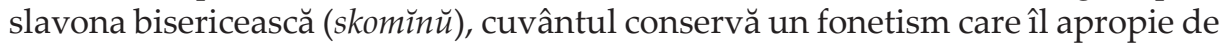
limba română veche şi de dialectele româneşti sud-dunărene (dr. dial. scamn, ar. scamnu, mr. scand, ir. skånd < lat. scamnum). Nu este lipsit de interes să menționăm faptul că teritoriul unde CKÓMEH formează arie compactă se află în fosta themă Paristrion (Panadunavon), creată de împăratul bizantin Ioan I Tsimiskis în anul 971 şi care cuprindea teritoriul Dobrogei şi al Bulgariei de nord-est (cf. N. Bănescu, Les duchés byzantins de Paristrion (Panadounavon) et de Bulgarie, Bucureşti, 1946). 


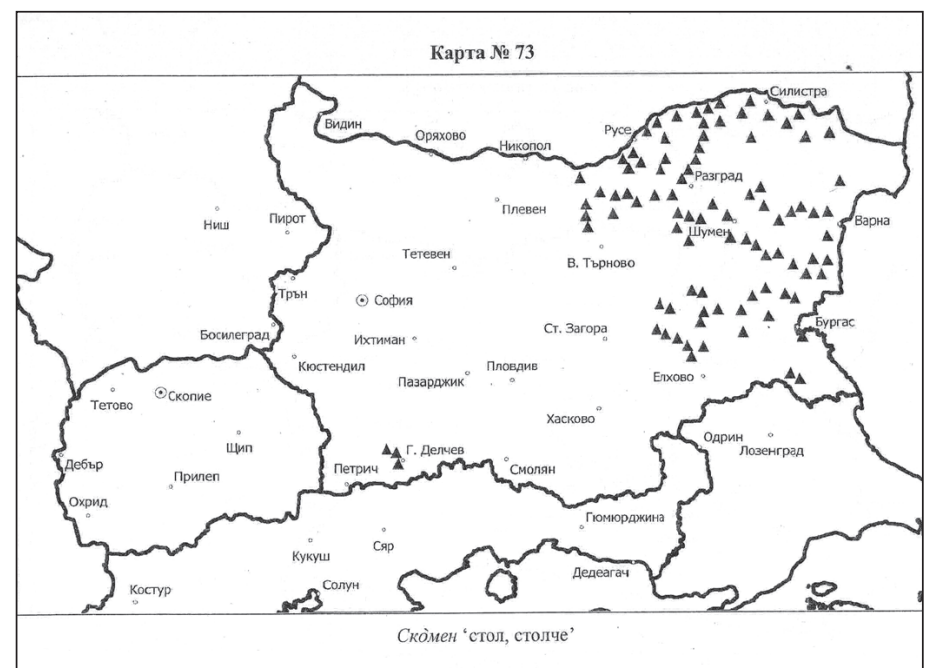

Este cunoscută extensiunea termenilor păstoreşti de origine română în limbile popoarelor învecinate. Dintre împrumuturile din acest domeniu, ca şi din cel al prelucrării lânii, în limba bulgară, prezentați de Th. Capidan în studiul său menționăm câteva: canură, căciulă, ciutură, colastră, curună, gună, urdă, etc. Lexic).

Mulți dintre aceşti termeni apar şi pe hărțile Atlasului dialectal bulgar (capitolul

Cuvântului УРДА îi sunt dedicate două hărţi din acest atlas: 25. Denumiri pentru urda preparată din zerul brânzei şi 26. Denumiri pentru urda preparată din lapte. Pe cele două hărți apare acelaşi termen УРДА într-o zonă din vestul Bulgariei, care se continuă în extremitatea sud-estică a Serbiei şi - ca arie extinsă şi compactă - în R. Macedonia de Nord. Cuvântul se întâlneşte, de asemenea, în graiurile slave din nordul Greciei (Macedonia, Tracia) şi din Turcia europeană. În limba română, de unde a pătruns în limbile sud-slave, urdă este un cuvânt autohton (cf. alb. udhos, *(h)urdë).

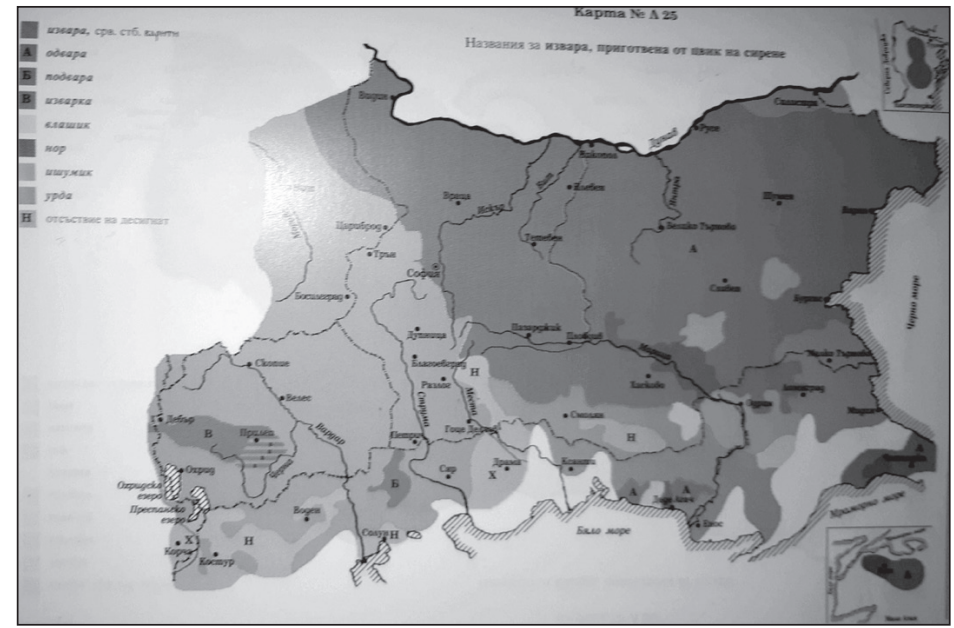


КОЛÁСТРА (ГУЛА́СТРА) 'coraslă; primul lapte după ce vita a născut'. Provine din rom. colastră, care e moştenit din lat. *colastra (colostra). Cuvântul se întâlneşte aproape peste tot în limba bulgară, cu excepția unei părți din sud, unde apare s'ára (séra). E atestat şi în estul R. Macedonia de Nord sub forma gulástra.
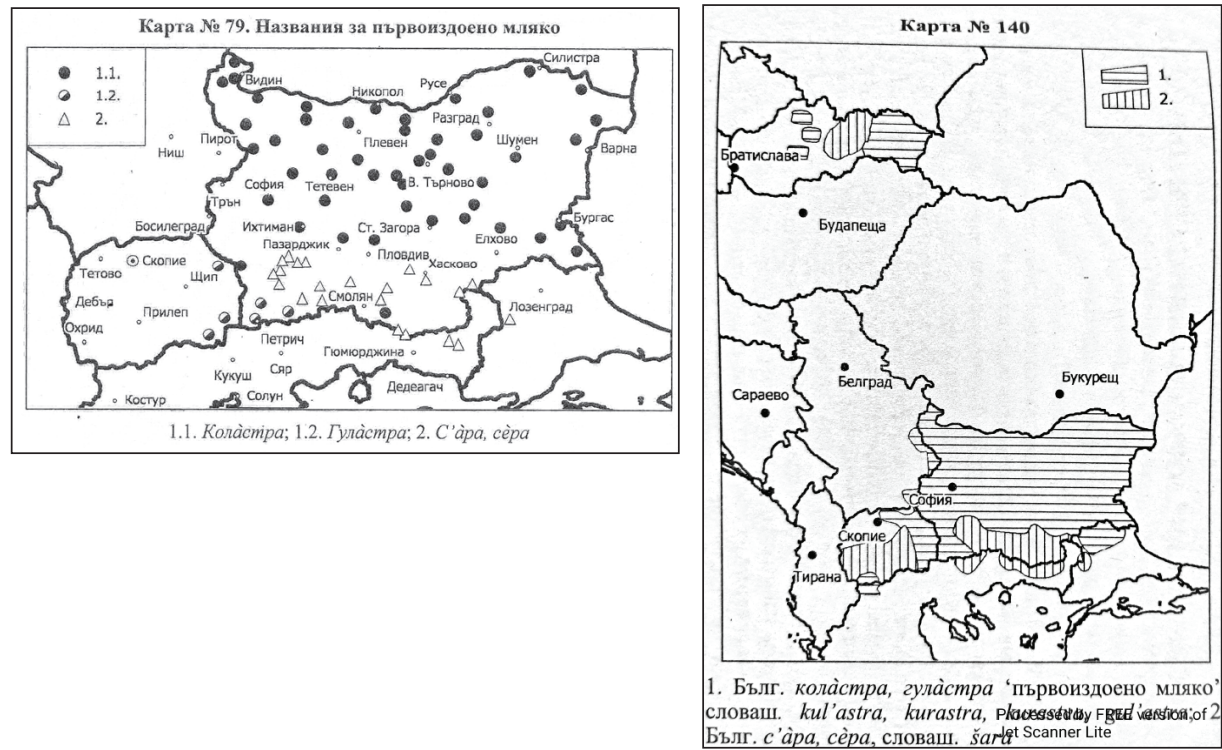

ГУН'А (ГУНК'А) 'sarică; zeghe'. Cuvântul cunoaşte o largă răspândire în limbile slave (cf. Mihăescu 1993: 458), regăsindu-se în albaneză (gunë, 'sarică') şi neogreacă ( $\gamma$ oúv $\alpha$ 'blană; haină de blană'), în aceste două limbi fiind considerat de origine latină: gunna 'blană'. Pe teritoriul Bulgariei, unde a pătruns prin păstorii vorbitori de limbă română, termenul e atestat în arii disparate, în nord-vest, sud şi sud-est (cf. ar. gună; cuvântul a existat şi în dacoromână). Se întâlneşte, izolat, în R. Macedonia de Nord şi în nordul Greciei (Tracia).

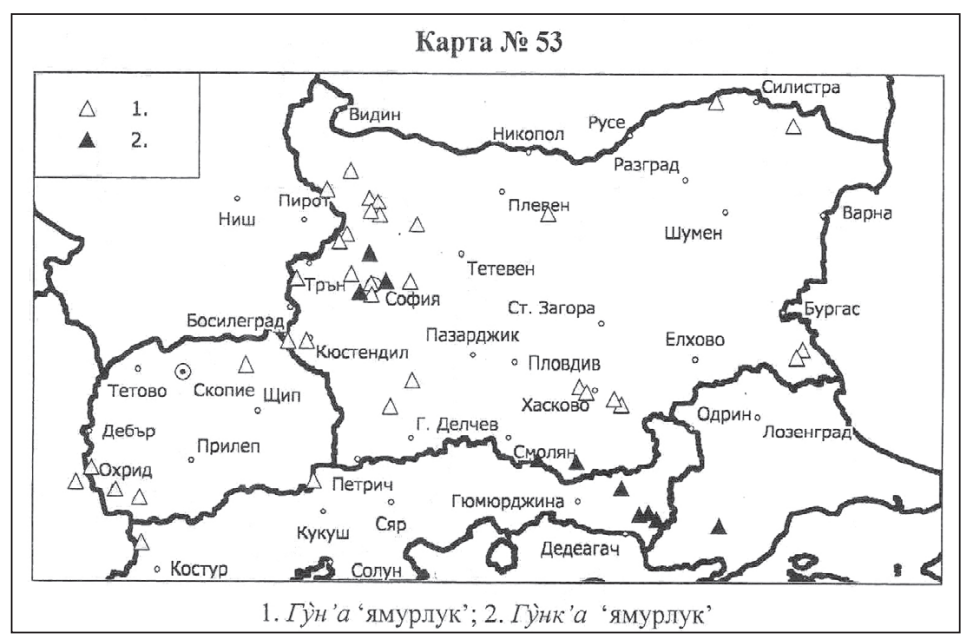


КУРУНА 'ramă la războiul de țesut'. Forma KУРУНA nu e înregistrată în dicționarele limbii bulgare literare, unde apare numai KOPÓHA 'cunună;

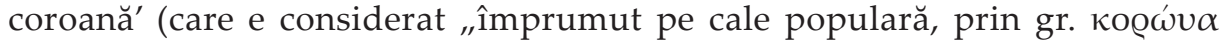
'cunună, coroană', din lat. corōna', BER II: 644). Sub aspect fonetic, KУPУHA e identică cu dr. (dial.), ar., mr. curúnă, ceea ce arată că termenul a fost preluat din limba română. Are o largă răspândire în limba bulgară, acoperind jumătatea de nord, nord-vest.

Un caz interesant îl reprezintă cuvintele ЧУТУРА şi КУТЕ $\Lambda$, ambele însemnând 'piuă', care acoperă cea mai mare parte a teritoriului Bulgariei. ЧУТУРА se întâlneşte în jumătatea nordică a Bulgariei, cu extindere în estul Serbiei, R. Macedonia de Nord şi extremitatea nord-vestică a Greciei. KУTE $\Lambda$ se întâlneşte în jumătatea sudică a Bulgariei, cu extindere în nordul Greciei (Macedonia, Tracia) şi în Turcia europeană (cf. BDA, harta lexicală 9). M. Mladenov reține în studiul său numai cuvântul ЧУТУРA (cf. Mladenov 1987/2008, harta 70), cu formă identică cu cea din limba română: ciutură. KУTEA e considerat în dicționarele limbii bulgare drept „împrumut din romanică, cf. lat. cotylus, *ciutulus", aceeaşi origine (lat. cotylus) având şi scr. kütao („din latina balcanică", după Skok) (cf. BER III, 156). Rom. ciutură (< lat. * cytola < catyla) s-a răspândit în limbile înconjurătoare (cf. DELR II, 1, s.v.).

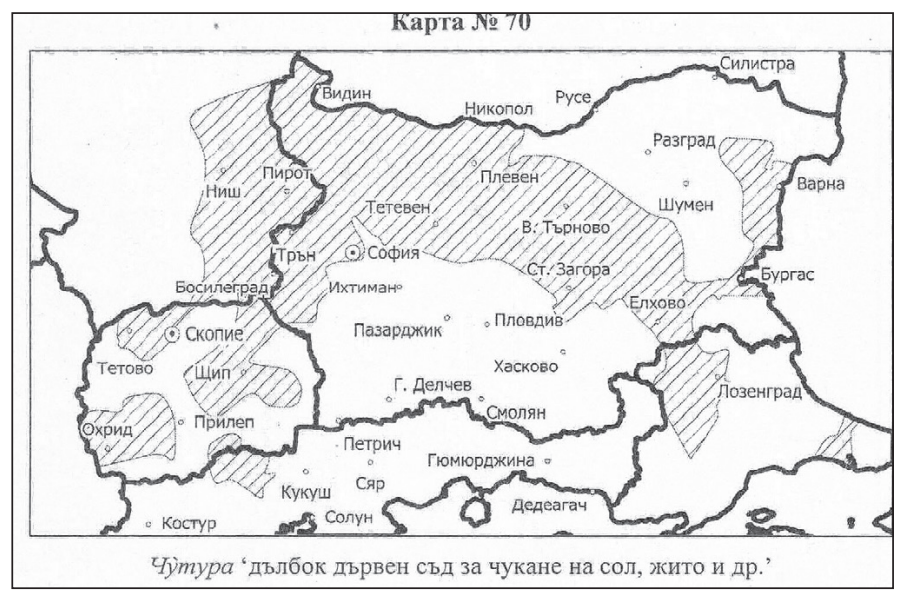

КАПИСТРА 'căpăstru' se întâlneşte în limba bulgară în două arii separate, una mai largă, în nord, care se întinde de la Vidin până la Veliko Tărnovo şi Ruse, şi alta restrânsă, în sud, care se prelungeşte în nordul Greciei (Tracia). Termen panromanic (cf. ILR II: 111), lat. capistrum s-a păstrat în toate dialectele româneşti (dr. căpăstru, ar. mr., ir. căpestru). Cuvântul apare în albaneză (kapistër) şi greacă ( $\kappa \alpha \pi i \tau \varsigma \rho \iota)$, unde provine din latină. Având în vedere unde se întâlneşte cu precădere КАПИСТРА în bulgară (arie largă în nord, izolată de cea din sud), considerăm că termenul provine din română, fără a exclude posibilitatea ca prezenţa lui în sudul Bulgariei şi la vorbitorii de limbă bulgară din nordul Greciei să fi fost sprijinită de gr. $\kappa \alpha \pi i \tau \varsigma \rho \iota$. 


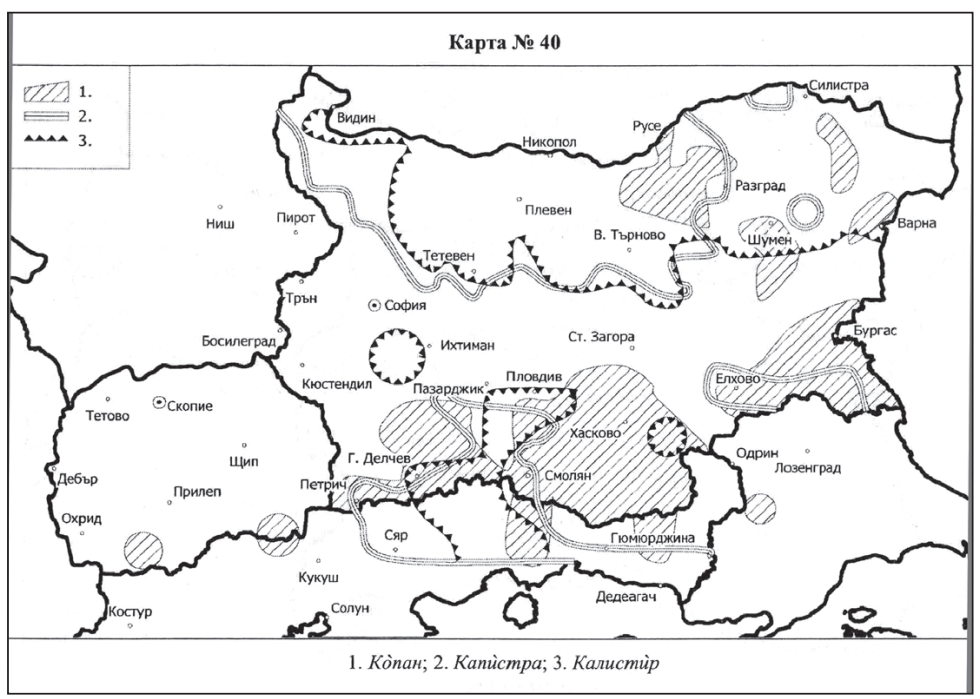

ФÁШA 'fâşie (şnur) de piele pentru opinci' e considerat un împrumut din rom. faşă (BER VII, 741). Are o arie largă de răspândire pe tot teritoriul Bulgariei (cu excepția părții de nord-est), întâlnindu-se şi în nordul Greciei.

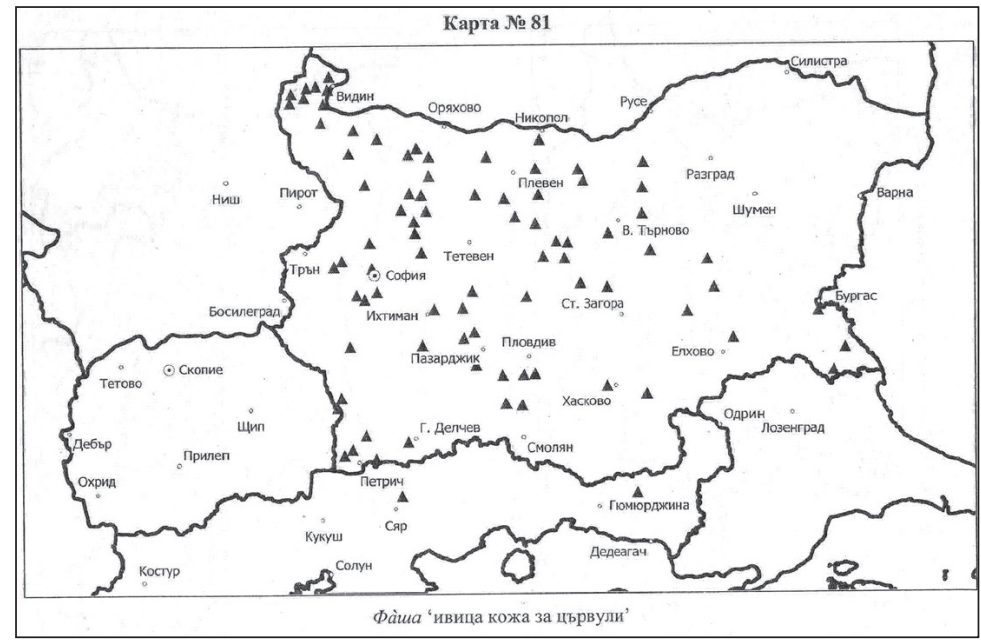

ТУФA 'tufă'. Înregistrat în nordul Bulgariei, într-o arie care se întinde de la Vidin, prin Plevna şi Veliko Tărnovo, până la Ruse, cuvântul bulgăresc provine din rom. tufă (dr., ar. túfă, mr. túfcă), moştenit din lat. tufa (cu descendenți în toate limbile romanice; cf. ILR II: 146). 


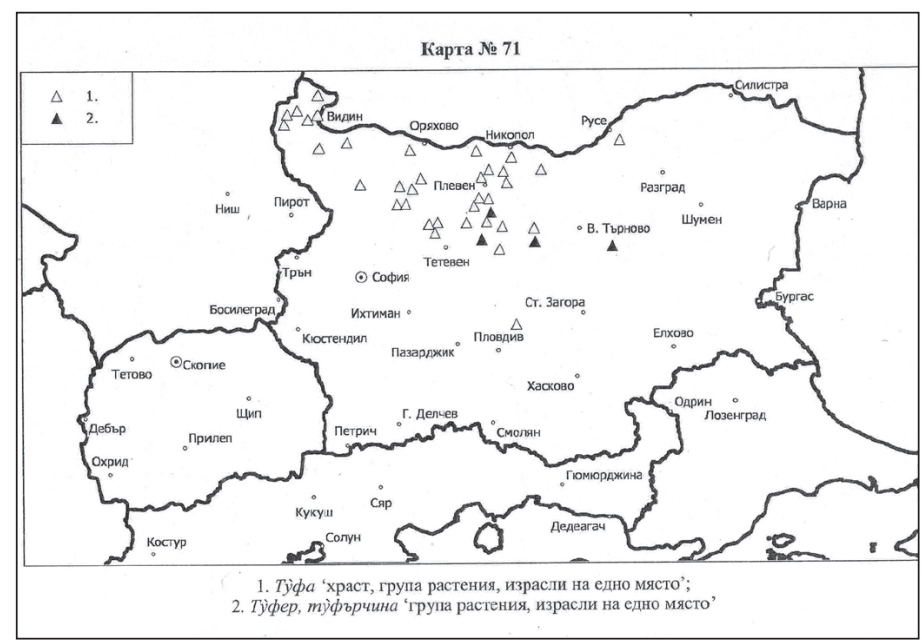

БÁУP 'melc; limax'. „După Candrea-Densusianu 172, din rom. *buăr 'bivol', care e o formă intermediară din lat. bubalus $>$ *buăr $>$ buar $>$ bour 'bivol', cf. rom. bourel 'melc', de aceeaşi origine. Melcul e numit aşa deoarece coarnele lui seamănă cu coarnele bivolului" (BER I, 94, s.v. БУХЕР, БУЕР); cf. CDDE 50-51, Capidan 1923: 176; Mihăescu 1993 nu reține cuvântul. Se întâlneşte într-o arie restrânsă, limitată la câteva localităţi situate la est şi sud-est de Sofia.

Din terminologia culturii materiale am reținut termenii СПУЗА, КОФТÓP (КОПТО́P), ТУРТА şi ПЕ́ТУРА.

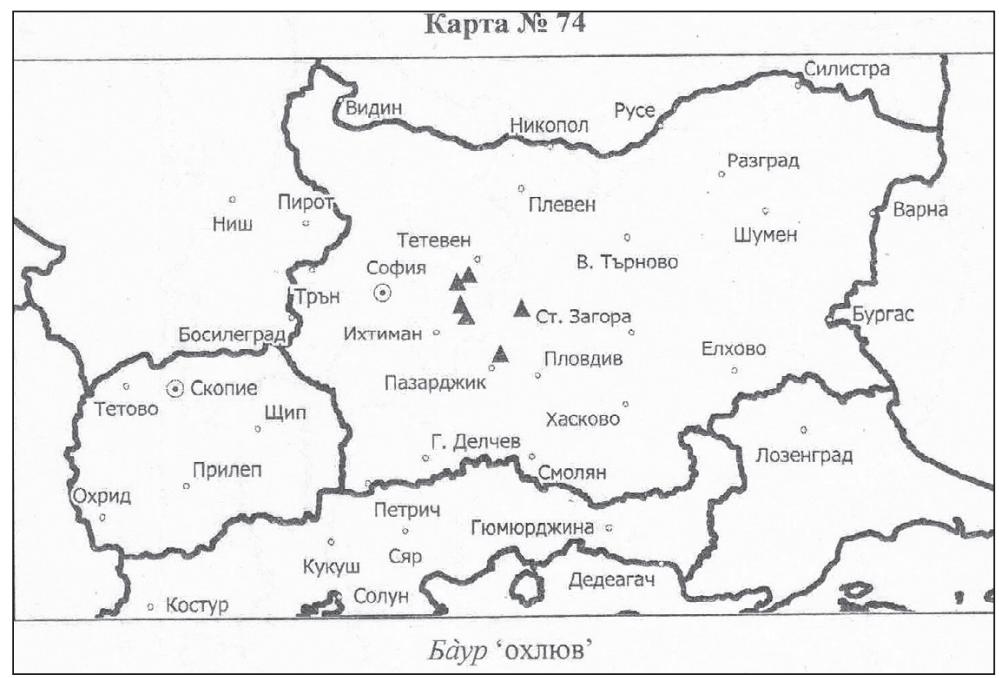

СПУЗА 'spuză' se întâlneşte pe teritoriul Bulgariei în câteva arii, una mai întinsă, în centru şi nord-vest (inclusiv zona Vidinului) şi alta în sud-vest, cu extindere în extremitatea nord-vestică a Greciei. Cuvântul apare şi sub forma ПУЗА (zona Veles-Kumanovo, în R. Macedonia de Nord, la graniţa cu Bulgaria), 
care ar proveni din CПУЗА (cf. BER V: 845). În bulgară cuvântul, considerat termen „popular” (cf. Dicţ.bg.-rom., 544) provine din română: spuză (< lat. spodia) (ILR II: 349). În dialectul aromân termenul curent e sprúnă (spúrnă), din lat. pruna, „cu s-, probabil, de la spodium" (DDA, s.v. sprúnă), dar e atestat şi spuză. Din aromână cuvântul a pătruns în dialectul grecesc din Epir (cf. Murnu 1902: 43, 91).

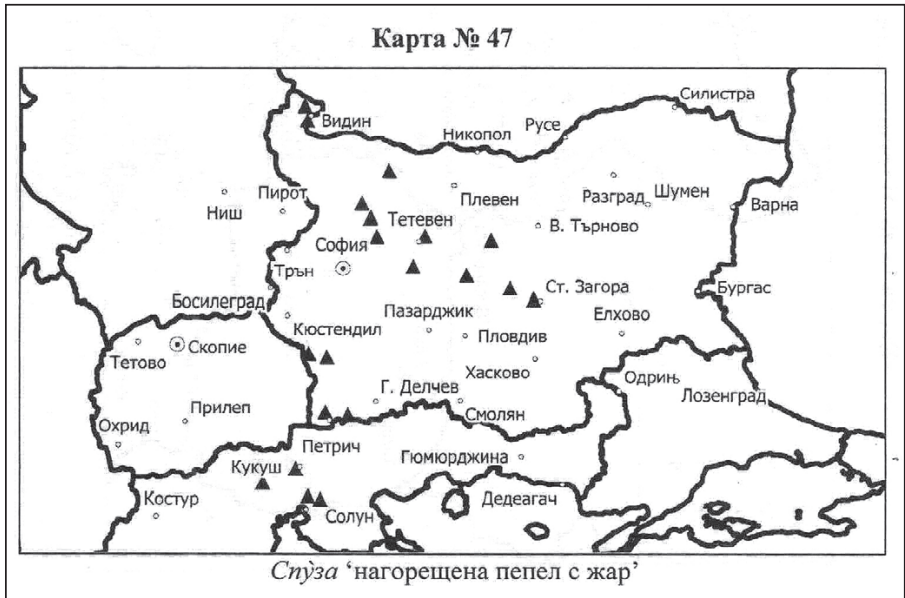

КОФТÓP 'sobă, cuptor', КОПТÓP 'cuptor în sobă'. Din rom. cuptor (< lat. coctorium) (BER II, 623). Sub forma KOФTOP apare în vestul Bulgariei, unde se întâlneşte şi ФУРНА 'cuptor zidit, pentru copt pâine', cei doi termeni desemnând realități diferite. КОПТÓP (influențat, ca formă, de dr. cuptor) se întâlneşte în nord-estul Bulgariei (Dobrogea de sud), între Silistra şi Varna, ca şi în zona Vidin-Plevna.

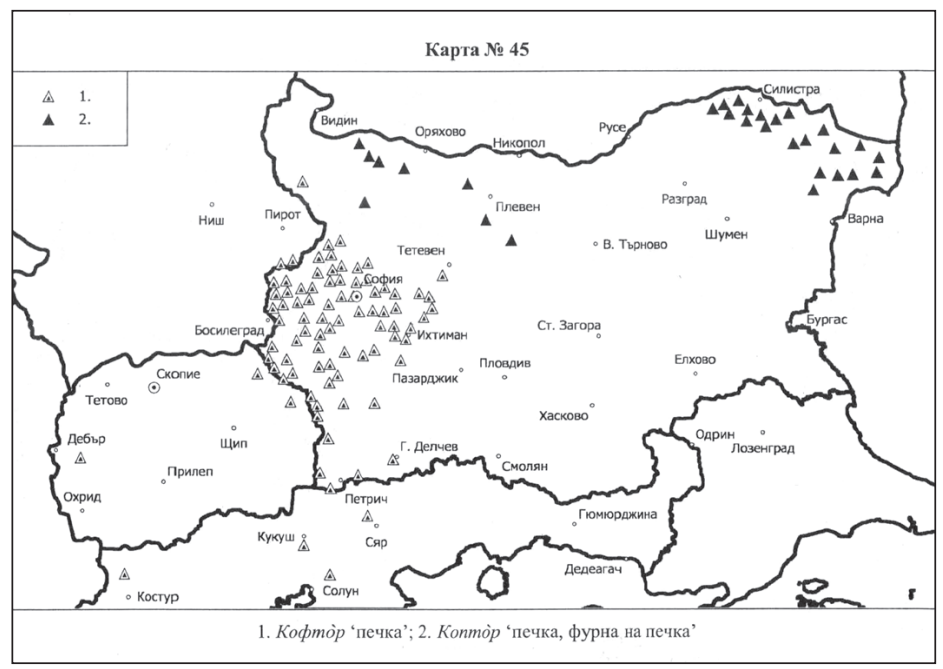

TУPТA 'pâine făcută fără drojdie'. „Din rom. turtă, care e din lat. torta” (BER VIII: 436). Cuvântul se întâlneşte în partea nord-vestică a Bulgariei, în restul 
teritoriului fiind înregistrat termenul ПИТА (ПИТУРКА), care se regăseşte în greacă $(\tau i \tau \alpha)$ şi italiană (pitta).

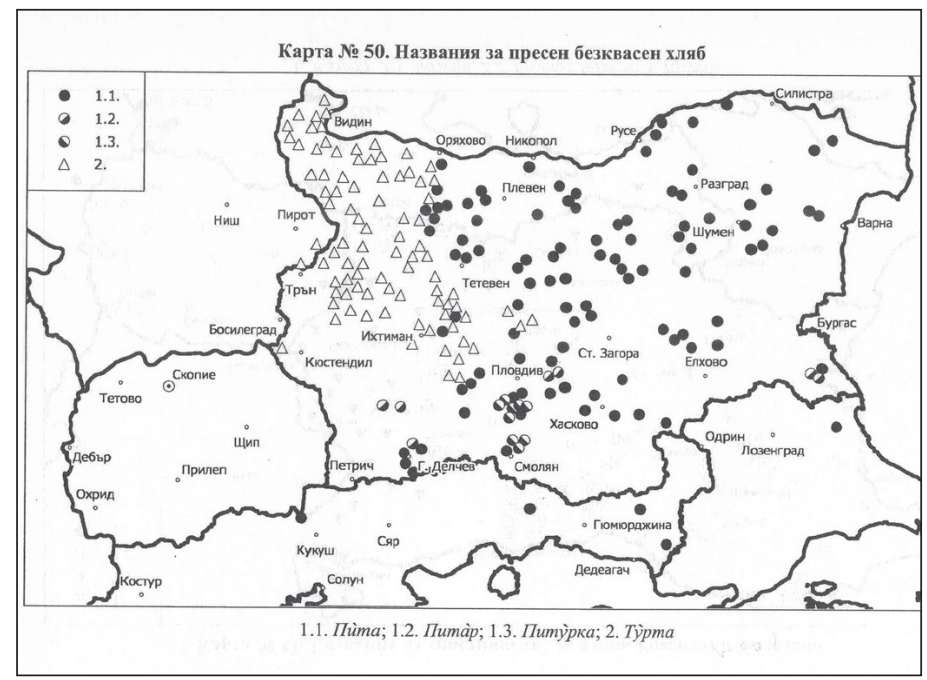

ПÉТУРА 'coajă (foaie) de plăcintă', „,̂̂mprumutat din ar. pétur, pl. péture, care, după Papahagi, e din lat. *pittula” (BER V: 206). „Sufixul -lus se păstrează în cuvinte izolate, fără valoarea diminutivală: [...], *pittula” (ILR II: 183, nota 7). Sub forma pétur 'foaie de plăcintă' cuvântul e general în aromână. Cu acelaşi sens, originar, sub forma pătură, se întâlneşte dialectal în dacoromână în subdialectul bănățean (cf. CDDE 232, s.v. pătură). E atestat într-o arie izolată, nu foarte întinsă, în centrul Bulgariei (cf. Mladenov 1987/2008: harta 76). Prezența vocalei $e$ (netrecută la $\breve{a}$ după labială) arată că e un împrumut vechi.

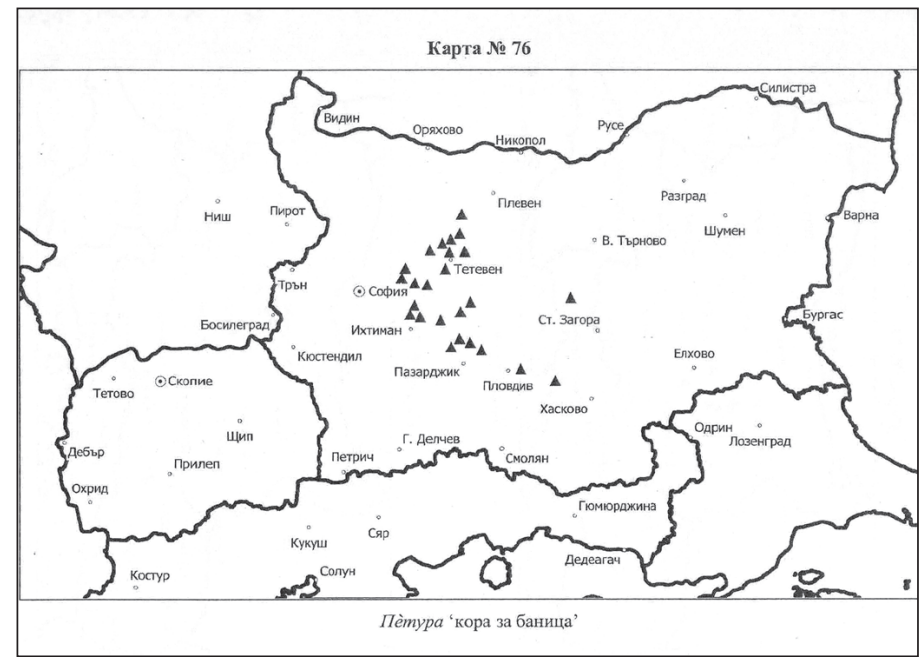

MÁTOP 'bătrân; matur; copt'. Din vsl. * mātarōo, *materō, înrudit cu lat. mātūurus 'matur, copt'; după Skok, din lat. mātūurus (BER III, 686-687). Cuvântul face parte 
din fondul panromanic, păstrat dialectal în română: ar. mătúr 'copt' (cf. ILR II: 112). În Bulgaria MÁTOP se întâlneşte într-o arie largă în centru, sud şi vest, alături de care apar derivatele mátorec 'bou de trei ani' şi mátorica 'scroafă'.

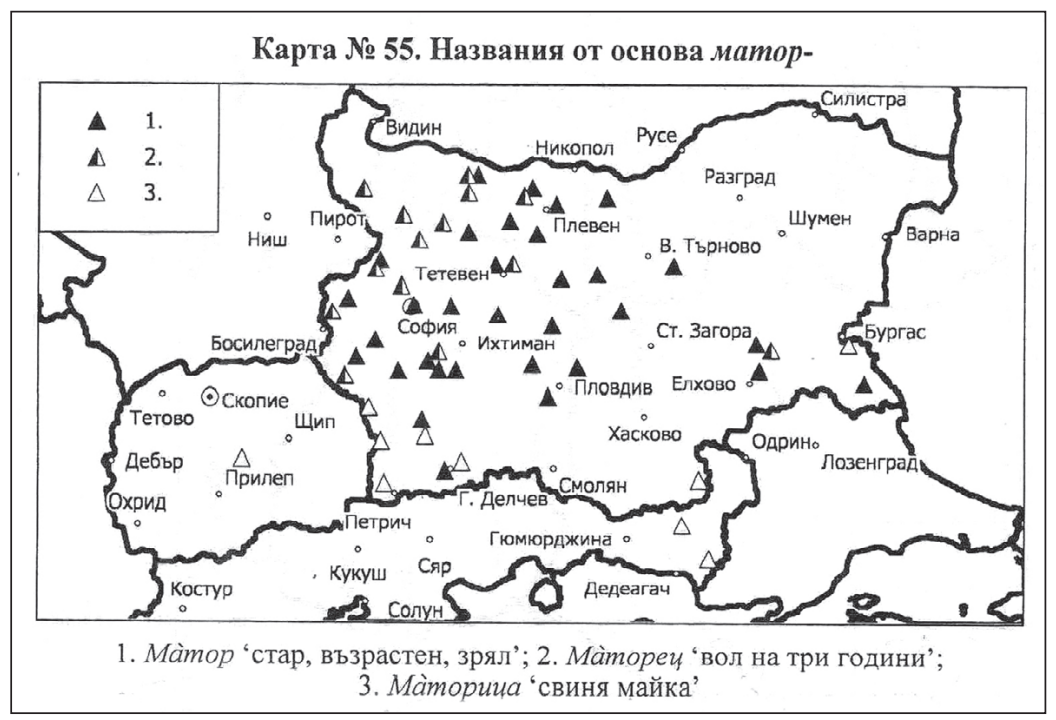

În contribuțiile studiate numeroase alte cuvinte din limba bulgară sunt aduse în discuţie în legătură cu posibila lor origine românească sau romanică. Observăm că autorii n-au ținut, în general, seamă de periodizarea istoriei limbii române, de aceea apar inconsecvențe şi oscilații în terminologia folosită, vorbindu-se de o influență romanică, latino-romanică, română ş.a.m.d. Situaţia e explicabilă prin faptul că unii din termenii analizați apar în spații largi romanizate, de la coasta dalmată şi Istria, unde slavii au venit în contact cu romanitatea apuseană (limbile dalmată, italiană), până în estul Peninsulei Balcanice şi Marea Neagră, unde contactele au fost cu romanitatea răsăriteană (limba română). În acest spațiu larg se vorbesc, în prezent, mai multe limbi sud-slave - croata, sârba, bulgara, macedoneana -, care, alături de elementele comune, prezintă şi particularități specifice.

Noi am încadrat cuvintele bulgăreşti discutate în categoria împrumuturilor din limba română, nu din latină sau latină-romanică, având în vedere faptul că, la data coborârii în sudul Dunării (începând cu secolul VII) şi în perioada următoare - secolele VII - X -, când s-au făcut împrumuturile, slavii au venit în contact cu o populație romanizată, care nu mai vorbea limba latină, ci limba română în perioada ei de formare - numită în lingvistica românească româna comună, proces care avea să se încheie în secolul al X-lea. Iată delimitarea geografică a romanităţii sud-dunărene la anul 1000: „Aceşti români, urmaşi ai romanităţii sud-est europene, formau în jurul anului o mie o pânză demografică aproape continuă, acoperind o bună parte a spaţiului balcanic, din zona Pindului şi a Thessaliei, cu ramificații spre Epir sau Peninsula Calcidică şi cu prelungiri spre Munţii Haemus, până la Dunăre, Sava şi Timoc" (ILR 2018/II: 288). 
Am ținut, de asemenea, seamă de faptul că unii termeni au pătruns pe căi diferite în limbile sud-slave: din romanitatea apuseană în limbile sârbă şi croată, din romanitatea răsăriteană în limba bulgară: „Croaţii şi sârbii [...] s-au orientat mai întâi spre Adriatica, pentru a roi puțin câte puţin spre est, prin valuri succesive, pe care savantul iugoslav Jovan Cvijić le numeşte «mişcări metanastasice»; doar mai târziu au venit în contact cu bulgarii, asimilând mai înainte populația romană intermediară. Organizați într-un stat dinamic, bulgarii s-au orientat mai întâi spre Constantinopol, dar s-au izbit de un sistem de apărare constând din fortificații greu de trecut, ceea ce i-a făcut să-şi devieze drumul spre vest, până la Marea Adriatică, aşa cum o dovedeşte toponimia slavă din sudul Albaniei" (Mihăescu 1993: 473).

În ceea ce priveşte teritoriul de formare a limbii române, care a fost fixat, în general, de lingviştii români, la nord de "linia Jireček”, care desparte zona de influență greacă la sud, de zona de influență latină la nord, menționăm concluzia la care ajunge lingvistul Maxim Mladenov pe baza studierii împrumuturilor romanice, respectiv grecești în limba bulgară: „Elementele lexicale romanice se răspândesc pe teritorii care se află de ambele părți ale liniei Jireček. [...] Esențial este să evidențiem faptul că nu există o legătură nemijlocită, directă între zonele de răspândire a civilizației medievale în partea de răsărit a Peninsulei Balcanice şi răspândirea actuală a împrumuturilor romanice (ca şi a celor greceşti)" (Mladenov 1987/2008: 241).

Studiul raporturilor lingvistice româno-slave din perspectiva geografiei lingvistice pune în evidență faptul că contactul dintre slavi cu populaţia romanizată s-a produs pe un teritoriu vast în nordul şi în sudul Dunării, pretutindeni acolo unde îi întâlnim în prezent pe vorbitorii de limbă română.

\section{Bibliografie}

Atlasul dialectal bulgar [Bălgarski dialekten atlas], vol. I - III (2001). Sofia: Editura Trud. Bănescu, N. (1946). Les duchés byzantins de Paristrion (Panadounavon) et de Bulgarie, Bucureşti: Atelierele „Cartea Românească”

BER II = Georgiev, Vl./ Gălăbov, Iv. / Zaimov, J./ Iliev, St. (redactor responsabil) (1979). Bălgarski etimologičen rečnik, II, Sofia: BAN.

Capidan, Theodor (1923). Raporturile lingvistice slavo-române. Influenţa română asupra limbii bulgare, Cluj.

CCDE = I.-A. Candrea, O. Densusianu (2006) [1907]. Dicționarul etimologic al limbii române. Elementele latine, G. Brâncuş (ed.), Bucureşti, Paralela 45.

DDA = Papahagi, Tache (1974). Dicționarul dialectului aromân, general şi etimologic, ediția a doua augumentată, Bucureşti: Editura Academiei Române.

ILR = Coteanu, I. (ed.) (1969). Istoria limbii române II, Bucureşti: Editura Academiei Române.

ILR $(2018 / \mathrm{II})$ = Saramandu, Nicolae, Romanitatea orientală (secolele IV-XV). Pe baza surselor istorice, în Marius Sala, Liliana Ionescu-Ruxăndoiu (coordonatori), Istoria limbii române Bucureşti: Editura Univers Enciclopedic Gold. 
Mihăescu, Haralambie (1993). La Romanité dans le sud-est de l'Europe, Bucureşti: Editura Academiei Române.

Mladenov, Maxim (1983). Bălgarsko-rumănski ezikovi areali, în Die slawischen Sprachen, V, p. 49-70.

Mladenov, Maxim (1987). Arealna harakteristika na romanski elementi v bălgarskite dialekti, în Die slawischen Sprachen, XII, p. 75-122.

Murnu, George G (1902). Rumänische Lehnwörter im Neugriechischen mit historischen Vorbemerkungen, München: Druck der Akademischen Buchdruckerei von F. Straub.

Puşcariu, Sextil (1926). Studii istroromâne. În colaborare cu M. Bartoli, A. Belulovici şi A. Byhan, vol. II. Introducere - Gramatică - Caracterizarea dialectului istroromân, Bucureşti: Cultura Naţională.

Skok, Petar (1926-1934). Zum Balkanlatein „Zeitschrift fur romanische Philologie", LV Halle a. d. Salle, p. 175-215.

Iovan, Tiberiu (1994). Dicționar bulgar-român, Bucureşti: Editura Ştiinţifică.

\section{About the Romance Element in the Southern Slavic Languages}

The contributions regarding the Romanian-Slavic linguistic relations have a long tradition both in Romania and in Croatia. Suffice it to mention a few names, from Petar Skok to August Kovačec in Croatia or from Al. Rosetti to Emil Petrovici in Romania.

The study of the Romance element in the Southern Slavic languages is part of the broader research on the Latin / Romance element in the Balkan languages. Recent works on linguistic geography represents a breakthrough in the study of language at the lexical level, including the study of borrowings. Based on the data contained in the linguistic atlases, we will bring back into discussion some aspects regarding the antiquity of the Romance element in the South Slavic languages and its territorial spread.

Key words: Romanian-Slavic linguistic relations, Romance element, Balkan languages, Southern Slavic languages, linguistic atlases 
